\title{
ENHANCING CREATIVITY THROUGH BATIK TRAINING AS AN ATTEMPT TO PRESERVE CULTURAL AWARENESS IN PRIMARY SCHOOLS
}

\author{
Laksmi Kusuma Wardani $^{1 *}$ Sriti Mayang Sari ${ }^{1}$ and Aniendya Christianna ${ }^{1}$
}

\author{
${ }^{1}$ Faculty of Art and Design, Petra Christian University, Indonesia
}

\begin{abstract}
Batik is an Indonesian cultural heritage that can enhance one's creativity in order to obtain independent achievements. Batik training is one that is conducted in the field of arts. Specific targets determined for this research are to assist primary students in discovering their talents, developing their skills and creativity in creating motifs that are sourced from the natural environment, implementing them in patterns, and training one's self through batik techniques. To achieve these goals, the research adopts the participatory action research method through training of batik writing and batik colet. Research results reveal that children are able to produce various creative works that are inspired by plants and animals. The increase of the student's creativity has been influenced by factors such as the student's personality, the facilitator as external motivational drivers, creative activity processes, and works as evidence of the children's learning outcomes.
\end{abstract}

Keywords: Batik training, children creativity, primary school

\section{Introduction}

Batik is a piece of wastra or cloth made with traditional technique of blocked dyeing using batik wax to prevent colors from penetrating (Doellah, 2002). The skill of batik has been passed down over generations. Batik is taught in non-formal institutions and some artisans are engaged in home industry for independent economic improvement. Batik contains local wisdom of Indonesian culture that may lead to enhance one's creativity towards an independent achievement. When we explore batik making, we will identify a number of techniques, methods, and cultural values supporting the establishment of character, personality, and disposition of a particular person. The basic idea of this study is that a good character has to be shaped and established since the early age. Therefore, the skill of batik making is a part of creative process that may lead to the improvement of independent attitude and behavior among children. Accordingly, children should have learned how to make batik since they are in primary schools. However, in Surabaya, there is not a single primary school that implement batik making in its academic curriculum. Primary schools should accommodate adequate local content in their curriculum in order to allow children to be familiar with cultural heritage and sustain them through cultural art works and vocational artisanship (Hsu, 20170. One of the objectives of art education is enhancing the creativity among children. Through art training, children will have acquire positive characters that shape their values of appreciation, critical thinking, and creativity through learning methods, media usage, and teachers. Batik training ensures the development of creative character. Students are expected to be responsive to visual forms, sensitive to environmental issues, and skillful in potential self-development. At the same time, students should be skilled at critical evaluation, have perseverant, thorough, and careful task accomplishment, as well as pride to one's self art works. They are expected to possess certain qualifications such as having factual knowledge in doing simple tasks using the specified tools, rules, and processes under the supervision of teachers. They should also be fully responsible for the process and accomplishment of the task.

Batik training is aimed towards cognitive development (knowledge), psychomotoric improvement (productive skill), and affective enhancement (attitude). This training emphasizes the importance of the learning of art and learning through art (Pinta, 2015). Training that is centered on cognitive development, psychomotor 
improvement, and affective enhancement will result in creative students. UNESCO (2009) reported that highquality education has to lead to the achievement of four learning principles. They are 1) learning how to be, 2) learning how to learn, 3) learning how to do, and 4) learning to work together. The implementation of the four principles will ensure the extensive enhancement of students' creativity in the society (Shaheen, 2010). Parents, teachers, and community play important roles in the enhancement of a child's personality. Therefore, both internal and external school environment should provide adequate free space for creative activities.

The objectives of this batik training, using the techniques of painting and brushing (colet), are to identify the children's talents, improve skills, and enhance creativity. The traditional technique of batik painting involves the application of batik wax on a piece of cloth using a pen-like tool called canting. The coloring technique of batik colet is done by applying colors using a paintbrush without dyeing. Therefore, this technique is more simple and easy to learn for primary school students. This activity ensures interaction between students, teachers, and trainers that accordingly, may lead to direct dialogue, suggestion, and transfer of knowledge and skill

\section{Research Method}

Formal educational institutions provide appropriate places for the students to learn in order that the students can optimally enhance their talent and creativity in compliance with their personal needs. Education institutions should encourage students to create creative works through creative activities or creative processes. The environment that provides chances and opportunities for the students to perform creative activities and creative processes will lead to the production of creative works (Munandar, 2002).

This study employs participatory action research emphasizing the principle of learning by doing. Students, teachers, headmasters, facilitators, and researchers were engaged in the study. The subjects of the study are grade 6 students of Sekolah Dasar Negeri Simolawang KIP 156 Surabaya and Sekolah Dasar Negeri Sidodadi II Surabaya. Data was collected through observation on the process and outcome. Descriptive analysis was employed in this study to describe the learning processes oriented to the enhancement of cognitive, psychomotor, and affective aspects (action planning) to result in creative works. Students underwent the following four action learning steps:

1. Students explored active traditional batik artisans to enhance students' skill (seeing, listening, and learning from experts), and explored the city park to enhance students' sensitivity to creative personal potentials using the environment as the source of ideas. It is expected that they can document various motifs of flora and fauna (factual data of observation).

2. Students produced designs to improve the students' creativity through batik motif making and composition development.

3. Students joined batik training to improve students' skill through the making of batik works using both painting and brushing technique.

4. Students held work exhibitions to obtain appreciation, criticism, suggestion, and compliment in an attempt to objectively evaluate the success rate of the learning program.

\section{Results and Discussion}

Batik training is intended for the transfer of knowledge (scientific knowledge of batik art), creativity enhancement (motif making, composition, and coloring), and skill improvement (technique of batik making). Creativity is a popular term in art and design. It particularly refers to creative activities that result in new ideas 
and innovation (Hurlock, 1978). The creative activities of batik training include introduction, knowledge transfer, and direct learning through seeing, touching, and feeling. Eventually, trainees will have to make or create an artwork. Acceptance, participation, and evaluation as parts of affective behavior will have to be enhanced since the early age. Knowledge, comprehension, analysis, application, and evaluation are intended to enhance cognitive aspects. Meanwhile, perception, preparedness, guided movement, accustomed movement, complex movement, movement adjustment, and work speed are intended to improve psychomotor aspects (Wardani, 2002). The creative processes in batik training will be further elaborated in the following discussions.

In the exploration of batik artisans, primary school students were expected to see, observe, know, and learn to know directly from the artisans in the batik home industry in Jetis, Sidoarjo, East Java (figure 1). The artisans shared knowledge about process, materials, tools, and their creative products. The skillful artisans shared their batik skills to the public since they are aware that batik has to be preserved by the new generation. Learning by directly observing artisans' activities and having a dialogue with them enabled the students to acquire knowledge regarding motifs, colors, and techniques. Therefore, students will be motivated to learn further.

The exploration of batik artisans also enabled the students to identify and explain the creative economic potentials and understand various kinds of creative products. Direct observation is needed to stimulate students' curiosity on something new or something that they have not studied at school. Students will give higher appreciation to traditional cultural values and the artisans' perseverance and creativity in the process of batik making. Outdoor learning through direct observation of artisans' activities is both enjoyable and educational. However, the information that the artisans gave to the students were occasionally not optimally recorded by the students.
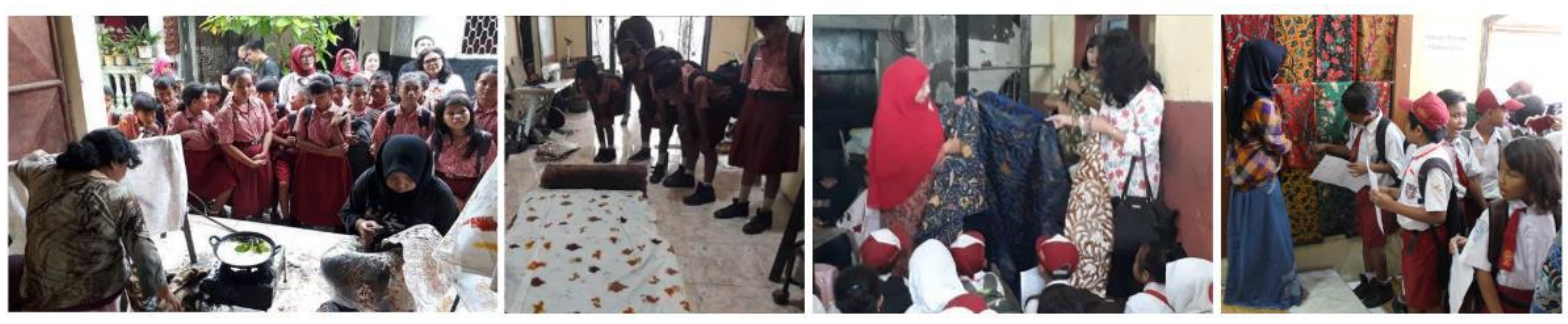

Figure 1 Students had a field exploration to the workshop of Batik Amri Jaya, Jetis, Sidoarjo, East Java Indonesia. The students enthusiastically watched and listened to the explanation of traditional batik making process. This exploration is beneficial for the students to be able to appreciate the artisans' profession. In addition, it is also useful for the students in identifying traditional art and culture existing and developing in local societies.

Therefore, teachers had to prepare worksheets to be filled up by students when they have an outdoor learning activity. They are requested to report what they have observed. However, in spite of the possibility of inadequate data recording in students' memory (optimally or less optimally remembered), this initial activity is beneficial and useful as a warming up exercise to enhance the children's creativity (figure 2). 

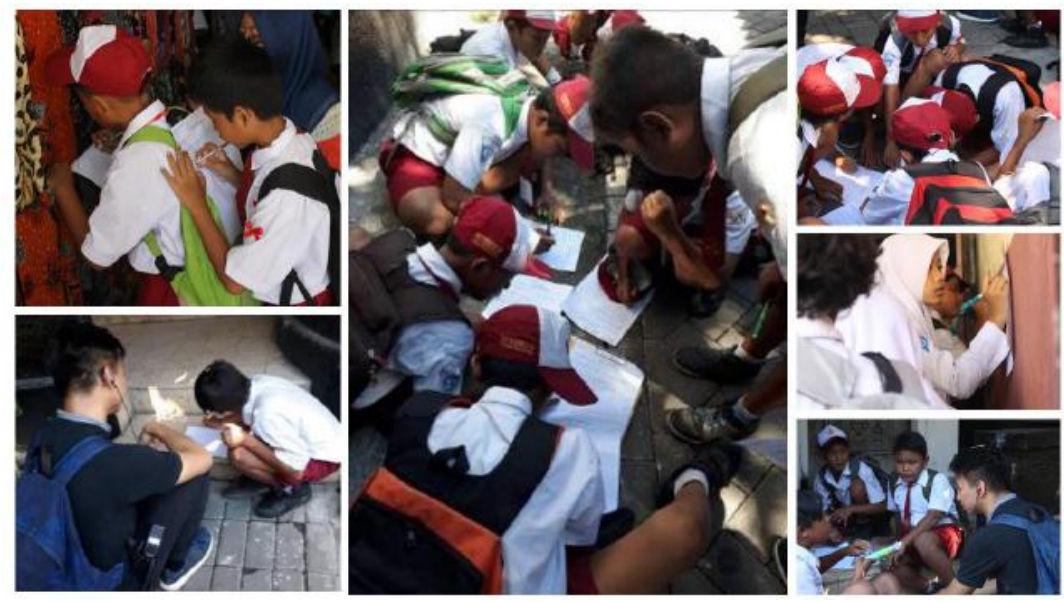

Figure 2 Students made a report in the batik artisans' workshop by filling up the worksheet prepared by the researcher to identify how much they can record the information provided by the artisans.

The students also had another exploration activity in the city park of Surabaya. The objectives of this activity are to provide a learning medium and to explore the natural potentials in the development of batik motifs. Environmental exploration encourages students' creative sensitivity with the environment being the source of idea. The output of the exploration is the documentation of various motifs of flora and fauna. In the activity, each school was divided into small groups with one facilitator. The facilitators were the students of interior design department of Petra Christian University. The researchers ensured that the facilitators and school teachers facilitated the students in observing the trees, leaves, flowers, animals, and other natural objects that can potentially be resources for the development of batik motifs (stimulating the emergence of idea through observation of natural objects) (figure 3). When the students have observed various kinds of plants and animals in the park, the students created their own motif after discussing it with the group and the facilitator. They imitated and drew what they have observed based on their own imagination. The students observed, recorded, and identified the potential and characteristics of the objects. Furthermore, they identified, selected, drew, and created alternative motifs based on observation of nature.

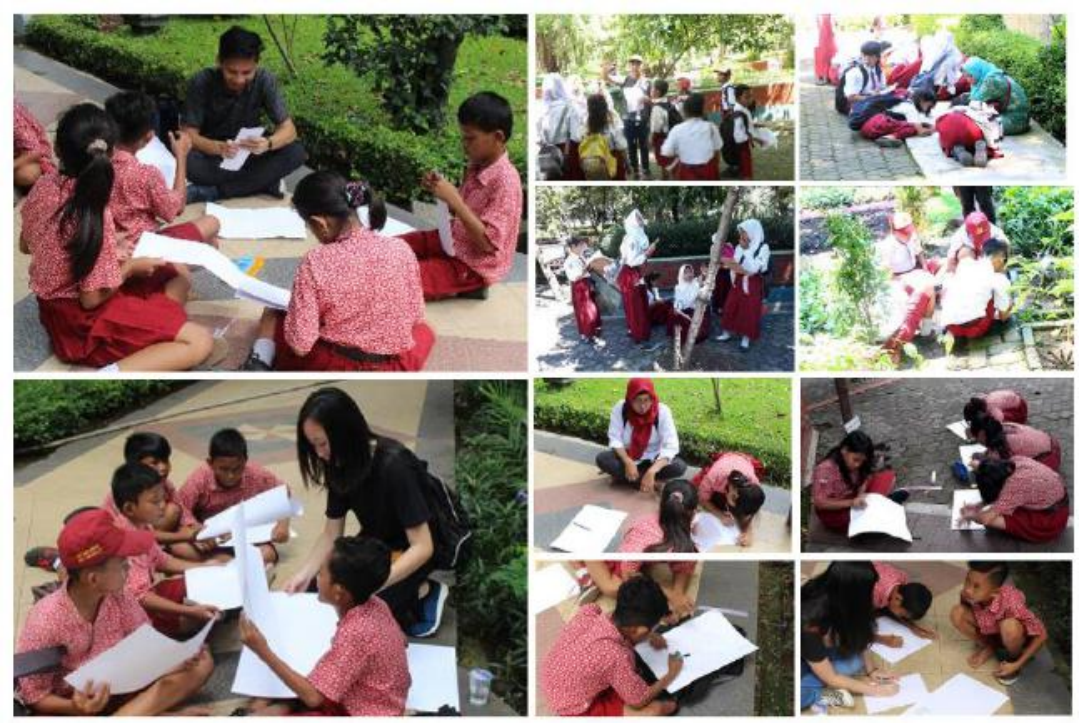

Figure 3 The students made motifs with the environment being their source of idea. They were facilitated by the facilitators and school teachers 
Natural environmental exploration is beneficial to identify various kinds of natural potentials. Equally important is that it encouraged the students' ability to identify their personal potentials that they are capable of making particular motifs and realized that they can find various kinds of alternative motifs based on environmental observation. The output of this exploration are various kinds of attractive, unique, and child-like flora and fauna motifs. Although they imitated what they saw directly, they created spontaneous and attractive forms of expressions (figures 4 and 5).
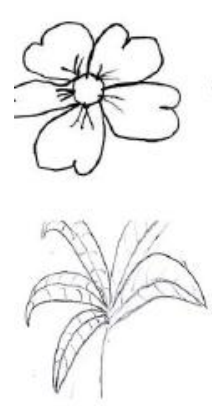
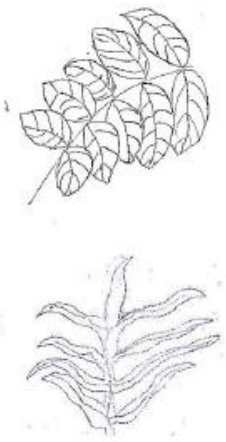
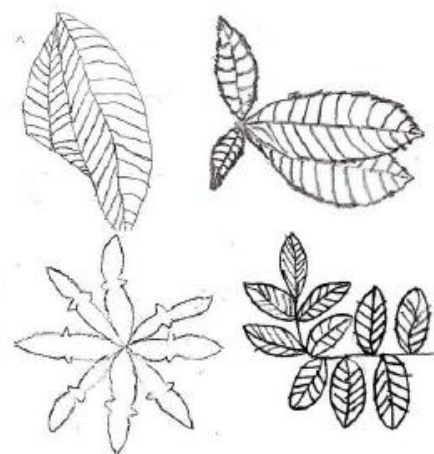

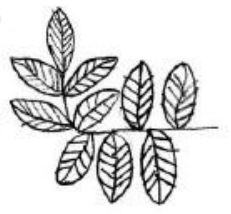

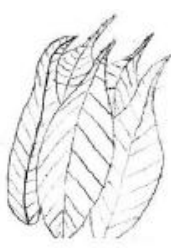

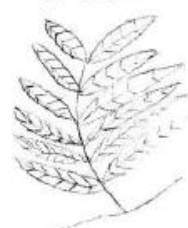

Figure 4 A number of sample leaf motifs created by the students of Sekolah Dasar Sidodadi II and Sekolah Dasar Simolawang KIP 156. Lines and arches are the shapes easily captured by children's visual sense. Therefore, the created expression is a well-arranged leaf. .

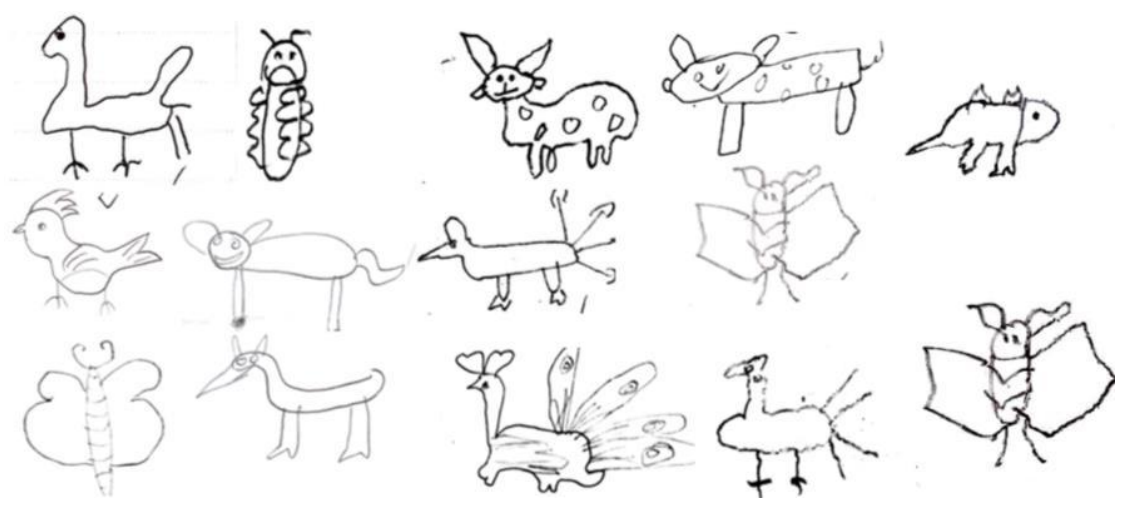

Figure 5 A number of sample animal motifs created by the students of Sekolah Dasar Sidodadi II and Sekolah Dasar Simolawang KIP 156. The students captured 3-dimentional shapes by their visual sense. Then they expressed them on a piece of drawing paper. They output was a two-dimensional shape. The shapes were the output of spontaneous expression, which was the specific characteristic of 10-year-old children.

In the design making, the teachers and facilitators assisted the students in identifying the uniqueness of their talents in a simple method. The tools and materials needed were only sample motifs made of paper, cotton cloth, and pencil (figure 6). In this training, two methods were applied. In the first method, the facilitators shared the motif already made by the students. Then they made a model with a piece of thick paper. Therefore, the students just made the composition on a piece of cloth based on the already prepared model. In the second model, the students made a motif with free composition on a piece of cloth. In the second method, the students were expected to have a free imagination and creation in a flexible time just like in the first method already practiced at school. Facilitators facilitated and divided the motif compositions into groups. The results of the activity indicated the students' eagerness in training. They were truly delighted and motivated. 


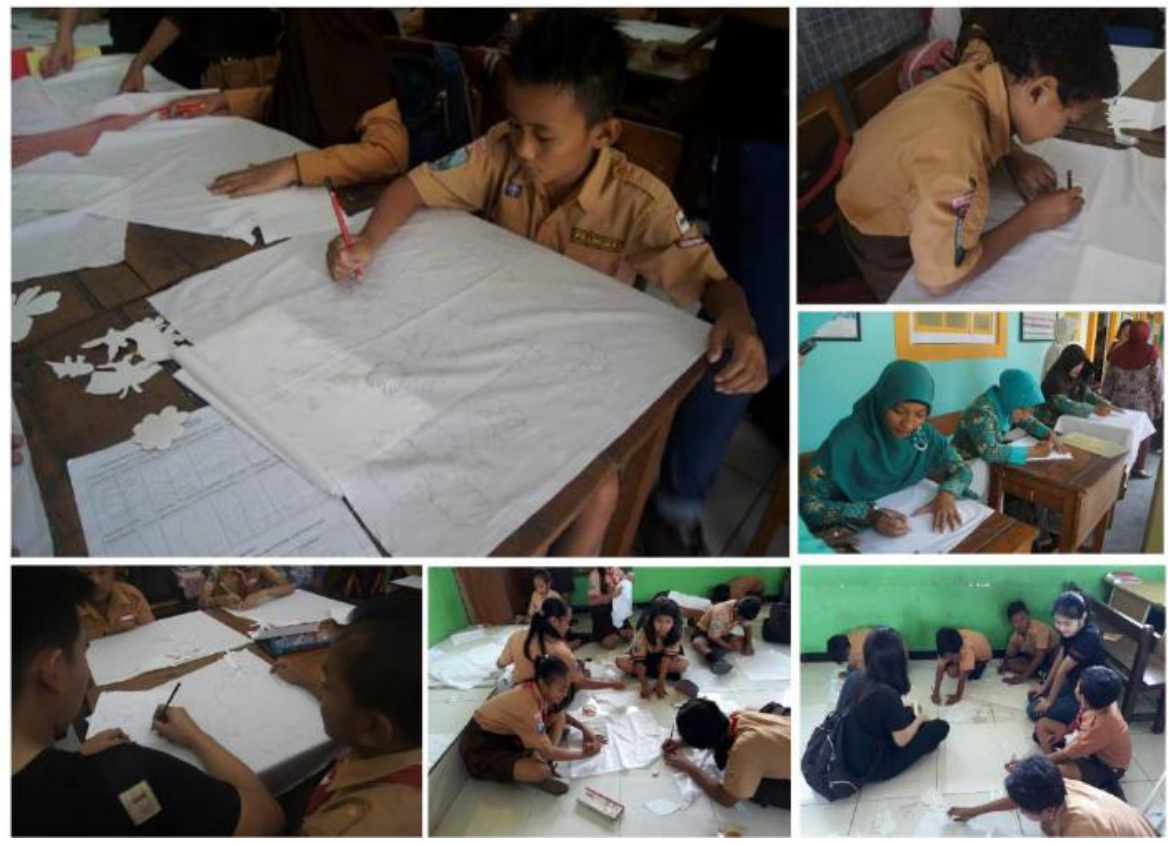

Figure 6 Stages of motif composition making on a piece of cloth using the model already prepared by the students. .

Batik training includes the transfer of knowledge/theory on batik integrated into batik making with simple techniques. The work of batik making starts from the application of wax on a piece of cloth by a pen-like tool called canting. The next step is the coloring with the Colet technique. The final step is the wax removal or locally known as nglorod. At the initial step of batik making, the traditional technique with canting was introduced to students. They practiced how to apply wax to the previously prepared motif composition. The tools and materials needed among others are 1) wax for nglowong; 2) medium-sized canting to make motif outline or nglowong and small-sized canting for isen-isen (filling) or cecek (dots), or large-sized canting to give emphasis on the lines to be distinguished, 3) wax boiler and stove filled with kerosene, 4) hurdle for hanging the cloth (Ministry of Trade republic of Indonesia, 2008).

Batik is made of textile colored with a particular specific motif and wax-blocked dyeing. The technique of batik making is the process ranging from the textile preparation to the batik completion. The preparation work includes the preparation of the textile including nggirah/ngetel (washing), nganji (starching), and ngemplong (ironing, calendaring). Students of primary school did not need to perform this task. They only needed the knowledge of basic techniques. The process of batik making includes wax application on particular motifs of textile, celup (dyeing), colet, painting, printing to the removing of wax from the textile (Susanto, 1980). Batik painting with colet technique involves the use of canting for painting and coloring on the expected motif and dyeing technique to provide basic color for the batik. In this project, the students accomplished these activities together with teachers and facilitators or trainers (figure 7). Teachers and facilitators helped students find the uniqueness of their talent and appreciate them through realizing their drawings in the form of batik motifs. Involvement of teachers in the learning process by practicing would result in the improvement of the students' self-confidence, because student motivation can be impacted by teachers instruction (Lia M. Daniels, Amanda Radil \& Amanda K. Wagner, 2016). The art education of requires teachers to construct learning experiences that generate creative products (Charles Gustina and Rebecca Sweet, 2014) 


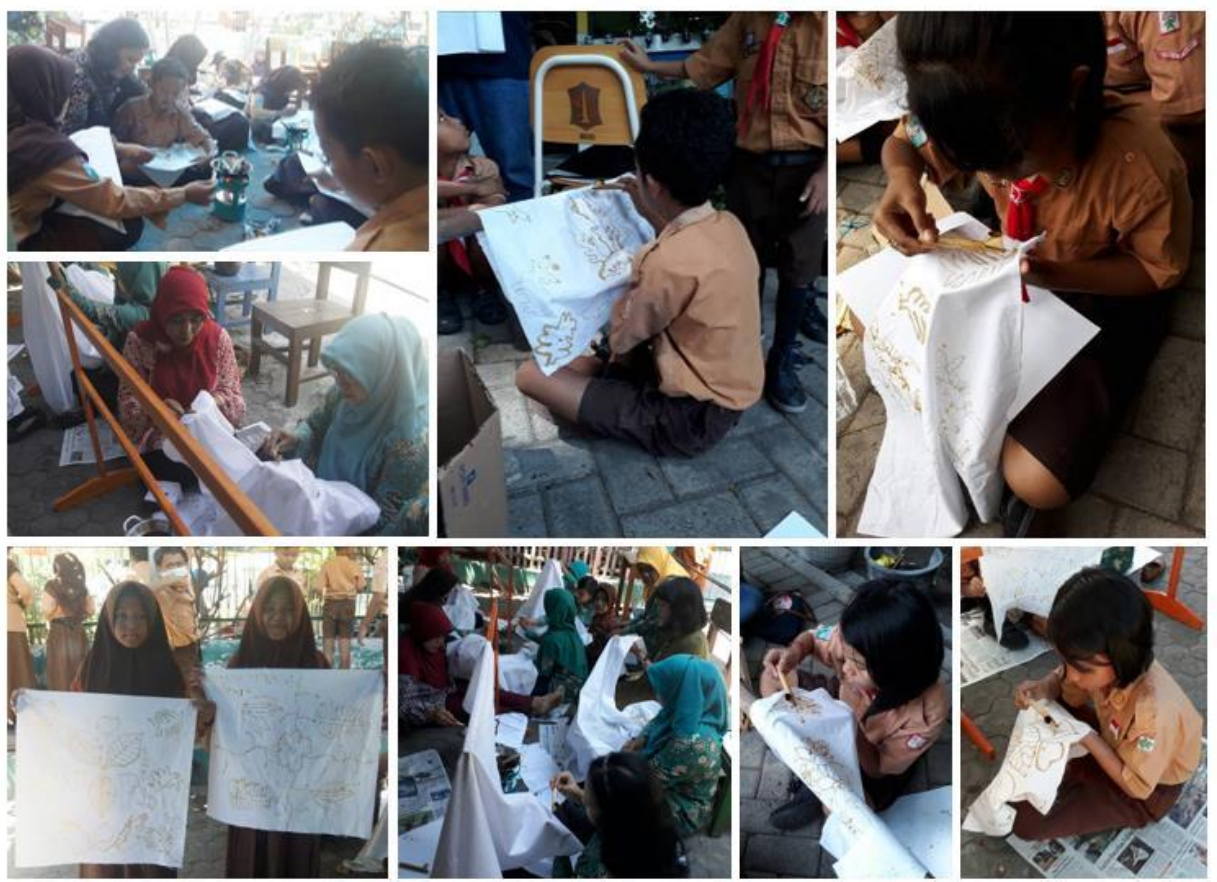

Figure 7 Stages of wax application on the textile with traditional batik painting using a canting. The students learn about perseverance, patience, meticulousness, and carefulness since they use hot wax.

The coloring process using the colet technique is an interesting creative process for students. Togetherness with teachers and facilitators can motivate students to learn more. Even the students will be motivated to try further. The coloring process used the remazol paint with the help of a brush (figure 8). Batik colors are obtained in different ways. First, batik can be colored with brush, drying, fixation, and nglorod (wax removing) and washing. In the process, the brushed textile is placed in a waterless solution for fixation. After that, the wax was removed from the textile in the boiling water. This process is known as nglorod. The textile is then dried in a place away from direct sunlight. The process is more simple and quick, without any process of dyeing as in the process of batik making with indigosol paint. Second, batik can also be colored with fifty grams of remazol paint per one liter of water, or five grams per $100 \mathrm{cc}$ of water. Third, coloring can be obtained by fixation with water glass or sodium silicate of $50 \%$ or $30^{\circ}$. Fourth, fixation takes 60 minutes at room temperature (cooling). Fifth, the batik colet still uses the batik painting technique through the process of nglorod without boiling. Sixth, to have a red color or the substitute color for one piece of textile ten grams of remazol paint $(200 \mathrm{cc}$ of paint solution) and 0.25 liters of sodium silicate solution of $50 \%$ or $30^{\circ} \mathrm{Be}$ or water glass would be required. At this stage, the researchers had prepared all materials for this project. 

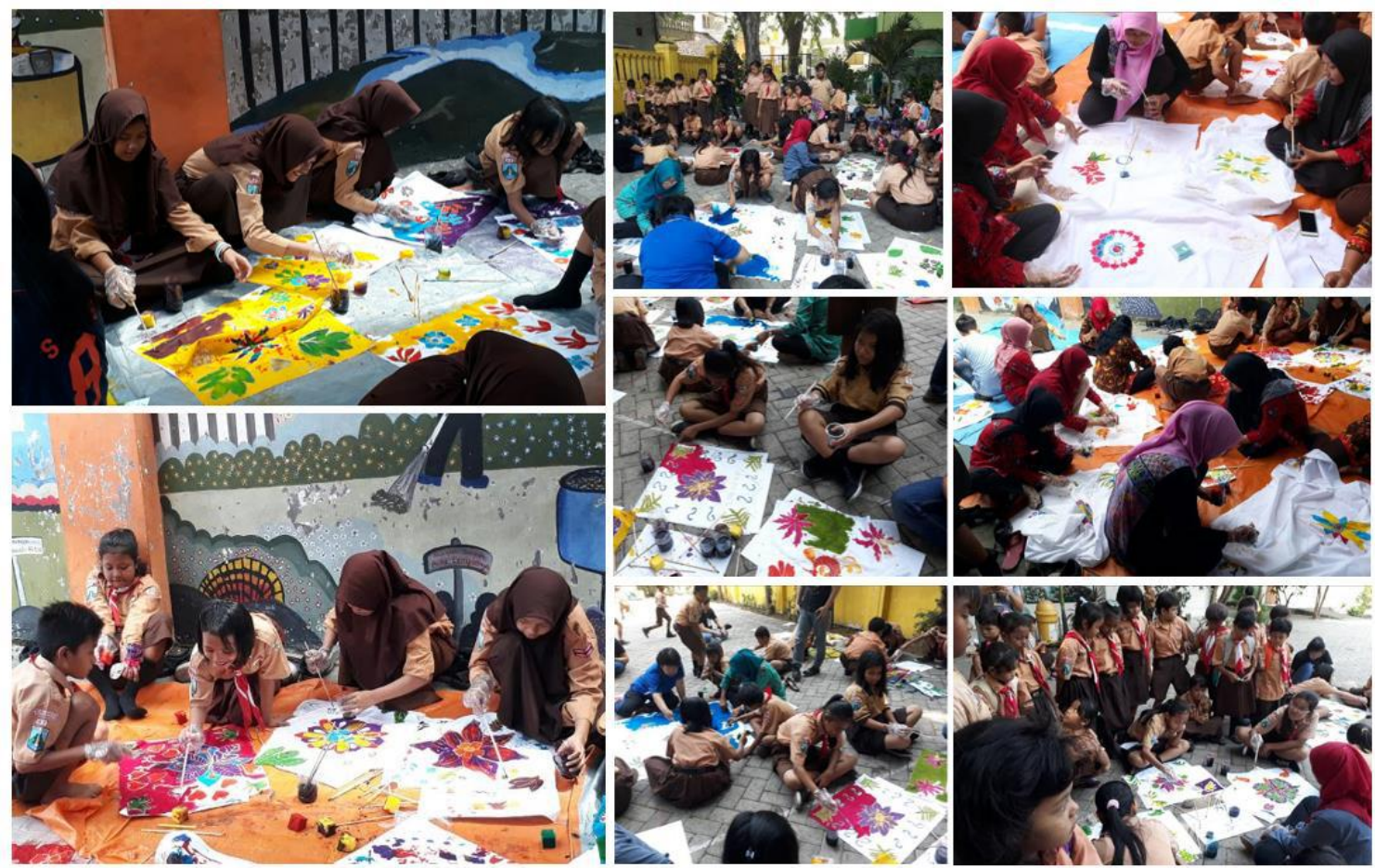

Figure 8 Coloring stage on the composition already made with the colet technique using a brush.

The evaluation of activities revealed that remazol paint is safe for children and hence for the primary school children. The process was simple and fast. It could be easily and practically applied like the usual process of batik making. Therefore, the colet process with remazol color did not require a new difficult technique. In addition, the color was bright. The real color would soon appear after the students apply the brush on the textile. This condition simplified the process of color composition making. The batik had a bright color and good quality. It was also economic and thus it is affordable to middle-to-lower groups. The application was also practical and simple. Water glass or sodium silicate was used for fixation or washing in order to ensure that the color did not fade. The selected colors for the colet process in the training were yellow, wine-red, Turkish blue, green, orange, violet, and pink. Meanwhile, the materials were size one and two oil paint brushes as the colet tools, cups to contain paint, foam to color large areas, cotton buds to color little motifs, and water glass for fixation.

After the colet process was over, the next process was fixation with water glass. The textile was dried at room temperature for several hours. In real practice, fixation takes minimally 1 hour. In this training, considering the limited time, the fixation took only 15 to 30 minutes before the textile was dried. After the textile dried, it was placed in boiling water (nglorod). It was then dried again. The evaluation revealed that the students were very happy and were eager to perform further experiments. The students carried out all the processes perseveringly and orderly. They passed the stages independently under the guidance of facilitators and teachers. The students were very proud of their final output. Teachers and trainers had been engaged in the training and working. They contributed much to the success of the activities. The students enjoyed the process of batik making with teachers and facilitators under the supervision of the headmasters and researchers. The students' works can be used for decoration of interior design elements. The bright color compositions make students' batik decoration distinguished when they are placed on the walls, a representation of the children's cheerful character in the learning process (figure 9). 

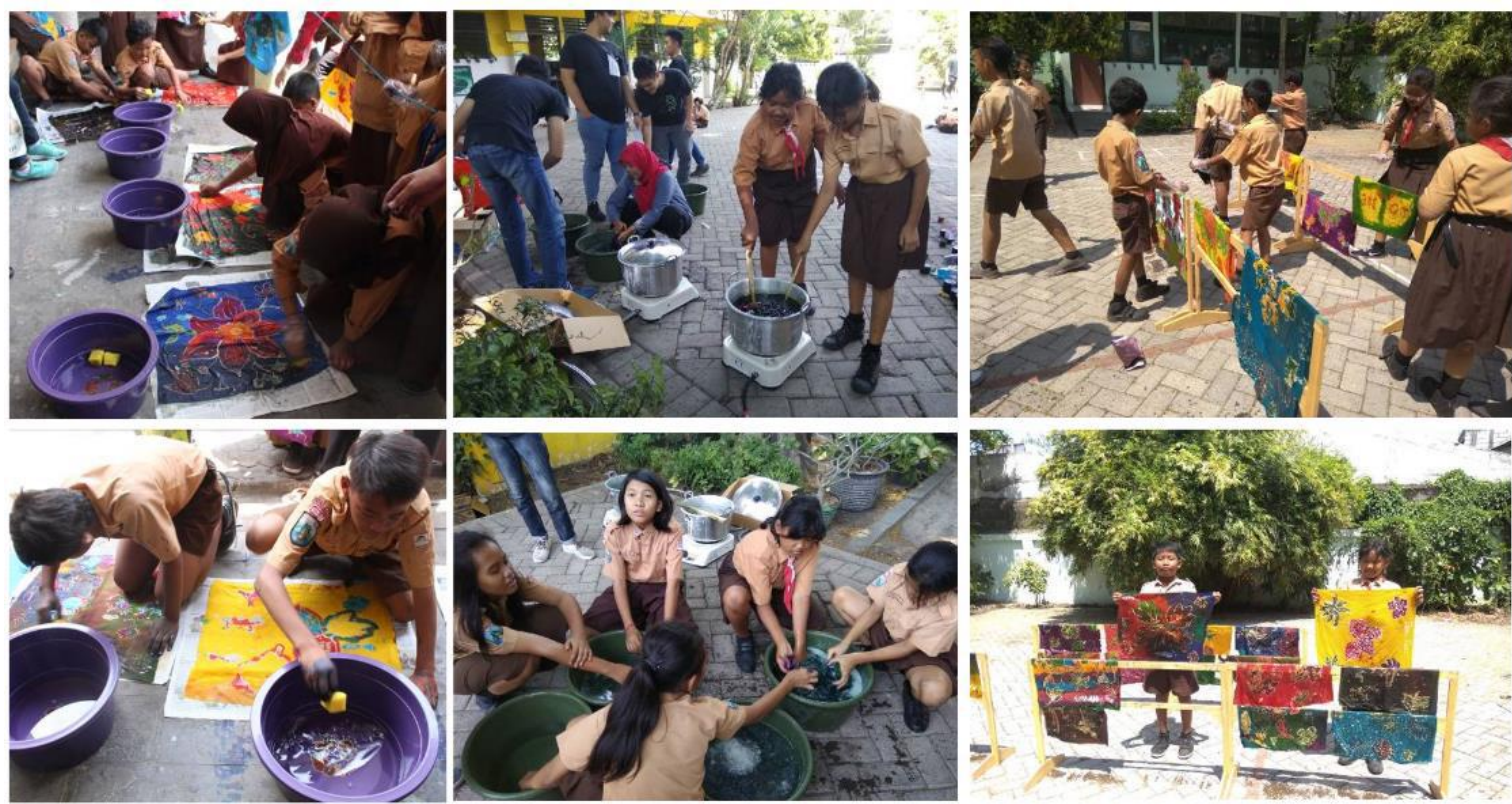

Figure 9 Fixation stage (the process of fixing the color to prevent from fading away) using water glass, removing the wax with boiling water, washing with cold water, and drying the batik.

The final activity was exhibition and joint work display. The exhibition is the final step in the training. Evaluation of the final works of the students revealed the display of student potentials as such as imagination, creation, and production of good works. This final step was an important moment for the students to show their personal existence and expression in the society. It was also intended to reveal students achievement to the society and to enhance self-confidence and self-awareness in one's potential (figure 10).

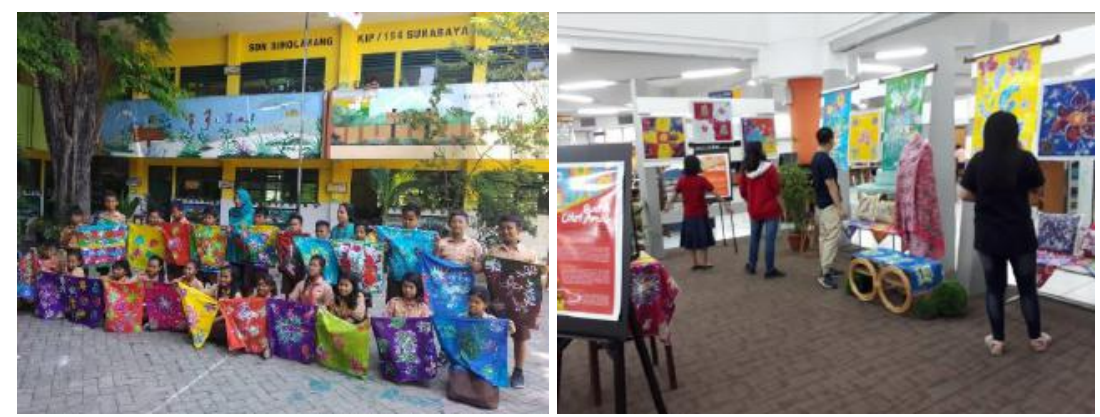

Figure 10 Joint exhibition as the final activity of the training to nurture the sense of pride among the students in the society.

The evaluation of the final products of the students revealed that the students generally applied free composition and centered arrangement, since the textile used for the training was in the form of square (figure 11). In general, the students were very happy with free expression. Initially, they were encouraged to use three motif compositions. However, they had their own creation and developed the compositions at their own will. 

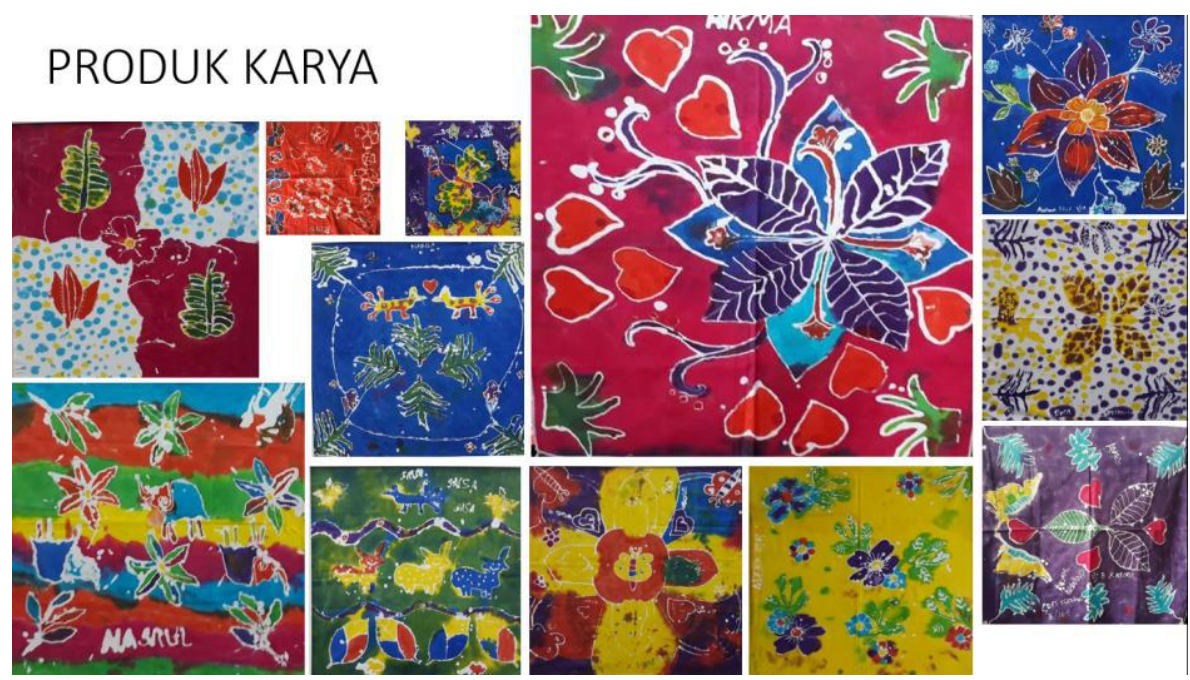

Figure 11 Students' final products representing the students' final expression in a free creation.

Overall, the evaluation results in batik training revelaed positive outcomes of the students' intellectual development as summed up in table 1 refers to the Bloom theory (Kevin Marjoribanks, 1980) and recommended pedagogical approaches (The College Board, 2012).

Table 1. Intellectual Behaviors Enhanced in the Batik Training for Primary School Students

\begin{tabular}{|c|c|c|c|c|c|}
\hline No & \multicolumn{2}{|c|}{ Stages of Batik Training } & \multirow{2}{*}{$\begin{array}{l}\text { Cognitive } \\
\text { Get acquainted and } \\
\text { familiar with various } \\
\text { kinds of batik technique } \\
\text { and the process of batik } \\
\text { production. }\end{array}$} & \multirow{2}{*}{$\begin{array}{l}\text { Psychomotoric } \\
\text { Students learn to } \\
\text { prepare, pay attention, } \\
\text { hear, see, record the } \\
\text { results demonstrated. }\end{array}$} & \multirow{2}{*}{$\begin{array}{l}\text { Affective } \\
\text { Students orderly pay } \\
\text { attention, ask, and } \\
\text { appreciate batik } \\
\text { makers and creative } \\
\text { resources. }\end{array}$} \\
\hline 1 & $\begin{array}{l}\text { Exploration } \\
\text { of technique } \\
\text { and skill of } \\
\text { batik } \\
\text { makers. }\end{array}$ & $\begin{array}{l}\text { Visit to batik } \\
\text { makers in the } \\
\text { surrounding } \\
\text { community }\end{array}$ & & & \\
\hline 2 & $\begin{array}{l}\text { Exploration } \\
\text { of natural } \\
\text { resource } \\
\text { potentials }\end{array}$ & $\begin{array}{l}\text { Visit to city park, } \\
\text { surrounding natural } \\
\text { environment. }\end{array}$ & $\begin{array}{l}\text { Know and understand } \\
\text { various kinds of motif } \\
\text { and natural potential } \\
\text { sources in the } \\
\text { surrounding } \\
\text { environment as the } \\
\text { source of idea in the } \\
\text { making of batik motifs. }\end{array}$ & $\begin{array}{l}\text { Students learn to } \\
\text { search, select, } \\
\text { determine, hold, touch } \\
\text { and write exploratory } \\
\text { findings, and study } \\
\text { within groups. }\end{array}$ & $\begin{array}{l}\text { Students are able to } \\
\text { identify, choose, } \\
\text { orderly discuss } \\
\text { options, and report on } \\
\text { exploration results. }\end{array}$ \\
\hline 3 & $\begin{array}{l}\text { Motif design } \\
\text { making }\end{array}$ & $\begin{array}{l}\text { Batik motif making } \\
\text { (various creations) }\end{array}$ & $\begin{array}{l}\text { Students are able to find } \\
\text { an idea and make } \\
\text { various kinds of motif } \\
\text { to be chosen in the batik } \\
\text { composition making. }\end{array}$ & $\begin{array}{l}\text { Reactions are directed, } \\
\text { imitations, create } \\
\text { motifs, designing } \\
\text { motives with the } \\
\text { group. }\end{array}$ & $\begin{array}{l}\text { Students are able to } \\
\text { discuss, perform, and } \\
\text { complete the making } \\
\text { of motifs }\end{array}$ \\
\hline 4 & $\begin{array}{l}\text { Design } \\
\text { making }\end{array}$ & $\begin{array}{l}\text { Batik motif } \\
\text { composition making }\end{array}$ & $\begin{array}{l}\text { Students are able to } \\
\text { compose simple motif } \\
\text { using the natural } \\
\text { composition technique. }\end{array}$ & $\begin{array}{l}\text { Students make a } \\
\text { reaction that is } \\
\text { directed, make } \\
\text { development, and try a } \\
\text { new arrangement, } \\
\text { designing with the } \\
\text { group. }\end{array}$ & $\begin{array}{l}\text { Students are able to } \\
\text { show, connect, } \\
\text { combine, organize } \\
\text { and refine the } \\
\text { arrangement of } \\
\text { motives. }\end{array}$ \\
\hline
\end{tabular}


Laksmi Kusuma Wardani et al/ Enhancing Creativity Through Batik Training As An Attempt to ....

\begin{tabular}{|c|c|c|c|c|c|}
\hline 5 & $\begin{array}{l}\text { Design } \\
\text { Criticism }\end{array}$ & $\begin{array}{l}\text { Reciprocal } \\
\text { observation, mutual } \\
\text { appreciation and } \\
\text { input to students } \\
\text { works among } \\
\text { students or between } \\
\text { trainers or teachers } \\
\text { and students }\end{array}$ & $\begin{array}{l}\text { Students are able to } \\
\text { criticize the strength } \\
\text { and weakness of } \\
\text { students works together } \\
\text { with the trainers and } \\
\text { teachers. }\end{array}$ & $\begin{array}{l}\text { Natural reactions, } \\
\text { showing each other a } \\
\text { good composition, } \\
\text { discussions with } \\
\text { teachers, facilitators, } \\
\text { and groups. }\end{array}$ & $\begin{array}{l}\text { Students listen to } \\
\text { input / accept or } \\
\text { reject criticism, able } \\
\text { to differentiate, } \\
\text { maintain, and } \\
\text { improve the results } \\
\text { already produced. }\end{array}$ \\
\hline 6 & $\begin{array}{l}\text { Design } \\
\text { making }\end{array}$ & $\begin{array}{l}\text { Developing the } \\
\text { composition } \\
\text { previously prepared } \\
\text { based on the inputs }\end{array}$ & $\begin{array}{l}\text { Students are able to } \\
\text { develop shape } \\
\text { composition based on } \\
\text { suggestion / inputs / } \\
\text { criticism from trainers } \\
\text { and teachers. }\end{array}$ & $\begin{array}{l}\text { Students improve, } \\
\text { make changes, and } \\
\text { work quickly. }\end{array}$ & $\begin{array}{l}\text { Students take the } \\
\text { initiative to improve, } \\
\text { follow the advice, } \\
\text { and make perfect the } \\
\text { results of their works. }\end{array}$ \\
\hline 7 & $\begin{array}{l}\text { Pattern and } \\
\text { composition } \\
\text { making }\end{array}$ & $\begin{array}{l}\text { Moving the motif } \\
\text { and composition of } \\
\text { batik to the textile }\end{array}$ & $\begin{array}{l}\text { Students are able to } \\
\text { make batik composition } \\
\text { pattern on textile. }\end{array}$ & $\begin{array}{l}\text { Natural reactions, } \\
\text { complex reactions, and } \\
\text { creativity are } \\
\text { developed by the } \\
\text { scraping of pencil on } \\
\text { the cloth }\end{array}$ & $\begin{array}{l}\text { Students follow } \\
\text { instructions, move } \\
\text { motives, organize } \\
\text { and adjust the media. }\end{array}$ \\
\hline 8 & $\begin{array}{l}\text { Wax } \\
\text { application }\end{array}$ & $\begin{array}{l}\text { Process of batik } \\
\text { painting on textile }\end{array}$ & $\begin{array}{l}\text { Students are able to } \\
\text { understand and } \\
\text { comprehend the } \\
\text { technique of batik } \\
\text { painting on textile. }\end{array}$ & $\begin{array}{l}\text { A complex reaction, } \\
\text { creativity is developed } \\
\text { by the drawing with } \\
\text { wax onto a cloth. }\end{array}$ & $\begin{array}{l}\text { Students carry out } \\
\text { their work, carefully, } \\
\text { diligently and } \\
\text { thoroughly practice, } \\
\text { and complete them. }\end{array}$ \\
\hline 9 & Coloring & $\begin{array}{l}\text { Process of coloring } \\
\text { with the technique } \\
\text { of Colet using a } \\
\text { brush }\end{array}$ & $\begin{array}{l}\text { Students are able to } \\
\text { comprehend and } \\
\text { understand the basic } \\
\text { technique of batik } \\
\text { Colet, choosing colors } \\
\text { and making } \\
\text { composition. }\end{array}$ & $\begin{array}{l}\text { A complex reaction, } \\
\text { creativity is developed } \\
\text { by painting the color } \\
\text { with a brush on a cloth }\end{array}$ & $\begin{array}{l}\text { Students perform, } \\
\text { practice, do their } \\
\text { work carefully, } \\
\text { patiently, diligently } \\
\text { and thoroughly until } \\
\text { completion }\end{array}$ \\
\hline 10 & Fixation & $\begin{array}{l}\text { Process of color } \\
\text { fixing with water } \\
\text { glass }\end{array}$ & $\begin{array}{l}\text { Students are able to } \\
\text { understand tools, } \\
\text { materials, techniques, of } \\
\text { color resisting } \\
\text { techniques in order that } \\
\text { the color does not fade } \\
\text { away }\end{array}$ & $\begin{array}{l}\text { Directed reactions, } \\
\text { complex reactions, } \\
\text { adaptation to ways / } \\
\text { techniques, tools and } \\
\text { materials }\end{array}$ & $\begin{array}{l}\text { Students obey and } \\
\text { abide by rules, and } \\
\text { adjust to the chemical } \\
\text { fluids used as media. }\end{array}$ \\
\hline 11 & Nglorod & $\begin{array}{l}\text { Process of removing } \\
\text { the wax from the } \\
\text { textile in the boiling } \\
\text { water }\end{array}$ & $\begin{array}{l}\text { Students are able to } \\
\text { understand tools, } \\
\text { materials, and } \\
\text { techniques of wax } \\
\text { removal from textile }\end{array}$ & $\begin{array}{l}\text { Directed reactions, } \\
\text { complex reactions, } \\
\text { adaptations to methods } \\
\text { / techniques, tools, and } \\
\text { materials }\end{array}$ & $\begin{array}{l}\text { Students obey and } \\
\text { abide by rules, and } \\
\text { adjust to the hot } \\
\text { chemical fluids used } \\
\text { as media }\end{array}$ \\
\hline 12 & $\begin{array}{l}\text { Washing and } \\
\text { drying Batik } \\
\text { cloth }\end{array}$ & $\begin{array}{l}\text { Process of washing } \\
\text { the residue of wax } \\
\text { from the textile and } \\
\text { dry it }\end{array}$ & $\begin{array}{l}\text { Students are able to } \\
\text { finish the final step by } \\
\text { removing the residue of } \\
\text { wax from the textile and } \\
\text { dry it. }\end{array}$ & $\begin{array}{l}\text { Directed reactions, } \\
\text { complex reactions, } \\
\text { adaptations to, ways / } \\
\text { techniques, tools, and } \\
\text { materials }\end{array}$ & $\begin{array}{l}\text { Students are able to } \\
\text { organize, develop } \\
\text { tolerance and } \\
\text { complete their task. }\end{array}$ \\
\hline 13 & $\begin{array}{l}\text { Exhibition } \\
\text { of Works }\end{array}$ & $\begin{array}{l}\text { Exhibition of batik } \\
\text { already made by } \\
\text { students }\end{array}$ & $\begin{array}{l}\text { Students are able to } \\
\text { make comparison and } \\
\text { show existence. }\end{array}$ & $\begin{array}{l}\text { Installing works, } \\
\text { composing and placing } \\
\text { works in exhibition } \\
\text { displays }\end{array}$ & $\begin{array}{l}\text { Students appreciate } \\
\text { each other's work, } \\
\text { and take pride in their } \\
\text { own work, learn } \\
\text { values of praise and } \\
\text { appreciation }\end{array}$ \\
\hline
\end{tabular}




\section{Conclusion}

The process of learning how to be, learning how to learn, learning how to do, and learning to work together can be successful depending on the of students' personal factors such as willingness to study, having a curiosity, willingness to try, and willingness to do. Such conditions had resulted from the engagement and motivation of teachers and facilitators. In addition, mutual observation and reciprocal suggestion contributed much to the success of the work. Students were motivated to achieve further. Through the process of batik training, students practiced and developed skills, and enhanced their creativity in the field of art. It was apparent that students were able to produce various kinds of creative works. From the research, it was found that batik training for primary school students is influenced by four factors. They are personal factor (willingness and motivation to learn), motivator (support, appreciation, and compliment from environment, teachers, parents, and community), process (opportunity provided by schools for students to be engaged in creative activity to produce creative works), and product creation (students' creative works).

Appreciation to the art inherited from the ancestors of Indonesia should be preserved over generations through formal education since early years of education in primary schools. The research has revealed that batik training can enhance the students' cognitive, psychomotoric, and affective behaviours and potentials. When the characteristics of art training that is adjusted to the competence, knowledge, and skills of primary school students, batik art training have the potential to develop into official education in formal education institutes with its specific techniques. Batik art can become a prospect for further development of the society and hence should be included in the curriculum of art and culture. As such, skillful teachers with excellent batik skills would be required in the future and this would start from existing teachers' willingness to learn and share with the younger generation.

\section{Acknowledgements}

This paper reported the public service activities financed by the Ministry of Research, Technology and Higher Education, Republic of Indonesia. The researchers are expressing the gratitude to partners such as headmasters, teachers, and grade 6 students of Sekolah Dasar Negeri Simolawang KIP 156 Surabaya and Sekolah Dasar Negeri Sidodadi II Surabaya, for their active participation in the training activity. Gratitude also goes to the students of Stratum 1 Program of Interior Design Study - Petra Christian University for becoming the facilitators/ trainers in this activity: Fausta Ottoni Sasi, Favian Grady, Livia Wijaya, Timotius Andrew, Yakub Christnsen T, Jovian Kurniawan, Annelis Iwasil, Grace Vianny, Mark Antoni Ryan, Joshua Sasongko G, Moses Amram, Agnes Nathania, Natalia, and Elizabeth.

\section{References}

Charles Gustina, Rebecca Sweet, 2014, Creatives Teaching Creativity, in International Journal of Art \& design Education, volume 33, No 1, 46-54.

Doellah, H. S., 2002, Batik: Pengaruh Zaman dan Lingkungan (Surakarta: Danar Hadi).

Hsu, L, 2017, Creativity in Art Methods Classrooms: Designing a That Looks Into the Kaleidoscope of Cultures. Art Education, 70, 13-21.

Hurlock, E. B., 1978, Perkembangan Anak (Jakarta: Erlangga).

Kevin Marjoribanks, 1980, Bloom's Theory of School Learning: an analysis, in Educational Studies, vol 6, No.1, 55-63. 
Lia M. Daniels, Amanda Radil \& Amanda K. Wagner, 2016, Concordance Between Preservice Teachers' Personal Responsibilities and Intended Instructional Practices, in The Journal of Experimental Education Volume 84, 529-553.

Ministry of Trade Republic of Indonesia. (2008). Indonesian Batik: A Cultural Beauty. Jakarta: TREDA. www.kemendag.go.id/files/pdf/2012/12/08/batik-id0-1354950532.pdf

Munandar, S.C. U., 1999, Kreativitas dan Keberbakatan: Strategi Mewujudkan Potensi Kreatif dan Bakat (Jakarta: PT Gramedia Pustaka Utama).

Pinta, S.R.H., 2015, The Influence of Noblewomen on the Batik Knowledge Construction and Role of Women in Rural Batik Sector, in International Journal of Humanities and Social Science, 5(5), 229-234. www.ijhssnet.com.

Shaheen, R., 2010, Creativity and Education, in Creative Education, 1(3), 166-169.

Susanto, S., 1973, Seni kerajinan Batik Indonesia, (Jakarta: Balai Penelitian Batik dan Kerajinan, Lembaga Penelitian dan Pendidikan Industri, Departemen Perindustrian R.I)

The College Board, 2012, Child Development and Arts Education: A Review of Recent Research and Best Practices, New York, N.Y. http://www.nationalartsstandards.org/sites/default/files/College Board Research Child Development Report.pdf

UNESCO 2009, UNESCO World Report: Investing in Culture Diversity and Intercultural Dialogue. http://unesdoc.unesco.org/images/0018/001847/184755e.pdf

Wardani, K.W., 2003, Berpikir Kritis Kreatif (Sebuah Model Pendidikan di Bidang Desain Interior), in Jurnal Dimensi Interior, 1(2), 97-111. http://puslit.petra.ac.id/journals/interior/ 